\title{
The Impact of Trade Liberalization on Labor Market of Developing Countries: What can Literature tell us?
}

\author{
*Zouhair Mrabet ${ }^{1}$, Charfeddine Lanouar ${ }^{2}$ \\ ${ }^{1}$ Université de Cergy-Pontoise UFR d'Economie et Gestion, Cergy-Pontoise Cedex France \\ ${ }^{2}$ Najran University Alsawadi, Najran, Saudi Arabia (KSA) \\ *mrabet2879@yahoo.fr
}

\begin{abstract}
This paper reviews recent developments of the impact of trade liberalization on labor market in developing countries (henceforth DC). Many studies suggest that there is a benefit impact of trade liberalization on abandon factor of production (unskilled labor in the case of DC). However, several others works show a reversal trend in these countries such as increased in relative employment and relative's wages of skilled labor. These later results contradict the prediction of Heckscher Ohlin Stolper-Samuelson model (HOSS) model. To reconcile theory with this empirical controversy some authors have tried to extend the traditional theory of international trade by relaxing one or more assumptions of model. The main message that can be learned about this problem is that neither empirical nor theoretical research have advanced an explanation for this puzzling. By comparing the result of the impact of trade liberalization on labor market in the Latin America and the East Asian regions, we show that differences in countries characteristics play a role to explaining this puzzling.
\end{abstract}

\section{Key Words: Trade Liberalization, Technology Change, Labor Demand, Wage}

\section{Introduction}

During the last two decades, several developed and developing countries have approved, after trade liberalization, a substantial increase in wages inequalities and relative labor demand. Empirical works on developed countries did not slice with the causes of this change occurred in the structure of labor market. Several studies ${ }^{1}$ show a positive links between international trade, level of wages and employment. This leads to conclude that the integration of the economies have undoubtedly contributed to the increase of wages dispersion and unemployment. Moreover, recent literature supports the idea following that technological change induced by trade liberalization could affects labor market. In this field of research, the DC has received a little attention. The first contributions have supported that trade liberalization in DC have an opposite impact on labor market compared to the developed countries. However, their experiences show mixed results, and attempts to understand the magnitude of this impact remain a complex task. During the last three decades, the DC has been the subject of several changes. First, at the beginning of 1980 decade, many DC have adopted a structural adjustment program in order to resolve the disequilibrium of their balance of payment sheet. These economic reforms, including trade liberalization, have caused a fast change in their labor markets. Second, the structure of protection, adopted by several DC since many years, determines the direction of resources allocation between activities. Therefore, productive factor remunerations are directly influenced by trade policies and industries orientation. Third, technology change, originated from developed countries, allows DC to undergo a fast technological modernization, which affects positively productivity. In fact, DC import rather than create their technologies that favorite the increase of demand for skilled labor. In contrast to developed countries where the tendency of this increase is consistent with the predictions of HOSS model, the result, for developing countries, is not as predictable 2 . Empirical results do not support a positive impact of trade liberalization on relative employment and wage of abundant factor in some DC; see for example Lee and Vivarelli (2006). Hence, an important question arises: how to explain that increases of wages inequalities and skilled labor demand in DC? Theoretical attempt to explain this unexpected deterioration of the relative wages and the demand of unskilled labor in DC have only appeared in recent years. The main explanation is that trade liberalization unchains a simultaneous process of technological change and an

\footnotetext{
${ }^{1}$ Several works analyse the causes of change of labour demand in developed countries. Two causes are largely discussed: trade liberalization and technological change biased towards skilled labor. For review of an empirical and theoretical literature, see Katz and Autor (1999), Slaughter (1998), Krugman (2000).

${ }^{2}$ Williamson, 1997; Arbache, Dickerson et Green, (2004); Goldberg et Pavcnik, (2005).
} 
increase of capital stock, causing a positive impact on relative labor demand of skilled labor that can increase wage dispersion. This paper has two mains objectives. First, it presents exhaustive theoretical and empirical literature reviews of the impact of trade liberalization on DC labor markets. For this objective, we review the principal lines of research that have tried to explain the recent evolution on the DC markets. Second, we present some economics characteristics that are used to explain the mixed finding of empirical works in DC. Precisely, we discuss why trade liberalization in some DC (East Asia) has a positive affect relative unskilled labor in contrast to others countries (Latin America) where a negative impact has been observed. The remaining of the paper is organized as follows. Section 2 presents some empirical evidences on wages and labor market demand of trade liberalization impact. Section 3 presents traditional and recent theoretical frameworks advanced to explain the mixture result. Section 4 present why there is no consensus about the impact of trade liberalization on labor market of DC (mainly between Latin American and East Asian countries). The last section concludes.

\section{What we can lean from empirical evidences?}

In the last three decades, DC has undertaken several reforms of trade liberalization. At the same time a structural change of labor demand in these countries have been observed. Many recent studies have tried to assess the magnitude of the impact of these reforms on labor market. Three assumptions have been investigated in recent empirical works. The first assumption suggests that the reduction of trade barriers reduces the skilled labor demand, by moving the structure of the production towards the intensive sectors in unskilled labor, as it is envisaged by the H-O theory. Precisely, they checked if the impact of trade liberalization plays an important role on labor market by assessing if it induces:

- An increase of relative prices of intensives unskilled labor goods.

- A positive impact on labor demand of unskilled labor.

- A reduction of wage premium which leads to a full of wage inequality in these countries.

- A share of skilled labor in all sectors increases due to the augmentation of relative remuneration of unskilled labor.

The second assumption suggests that reduction of trade barriers increases the relative demand of skilled labor by moving the production structure towards sectors intensives in skilled labor; see Feenstra and Hanson (1997). The third assumption supposes that reduction of trade barriers increases the relative labor demand of skilled labor, by increasing the use of biased skilled technology, see for instance Pissarides (1997) and Berman and Machin (2000). In addition, as suggested previously, there are relatively few empirical studies, for the case of developing countries that have investigated the impact of trade liberalization on labor market. Two variables are generally used to explain these links: wages and relative labor demand. Thus, in subsection 2.1, we will present the wages evidences and in subsection 2.2, we will present the relative labor demand evidences.

Wage evidences: An important theoretical result that investigates the impact of trade liberalization on wages emerges from the Stolper-Samuelson theorem, which predicts that wages inequality between skilled and unskilled labor should decrease when the country is abundant in unskilled labor, such as the developing countries. In addition, as suggested by the traditional theory, when DC opened their economies to trade, the demand and the price remuneration of abandon factors increase compared to the scares factor. Unfortunately, this theoretical result is not observed in practice for some DC and particularly for Latin America, (Robbins 1996, Wood 1997, and Arbache 2001). In the rest of this section, we will present some empirical evidences that have investigating the impact of trade on labor market and more especially on wage. Hanson and Harrison (1999) have examined the wages and employment change of skilled and unskilled labor after trade liberalization in Mexico. They find a little variation of employment level, but a significant augmentation in the relative wages of skilled labor. They also find that the foreign firms and those exporting distribute a higher wages for skilled labor. Robbins $(1995,1996)$ examines the impact of export increase on the changes of wages gap between skilled in many Latin American and East Asian countries, he finds that large trade liberalization leads to a fall of wage inequality between skilled and unskilled labor in the majority of East Asian countries ${ }^{3}$. Whereas, in the Latin American countries there is evidence of an increase of wage gap between qualifications. This has been attributed, especially, to the changes in demand side. Robbins and Gindling (1999) studied the

\footnotetext{
${ }^{3}$ The countries, which show an ambiguous negative relation between the wage inequality and trade liberalization, are Hong Kong, Korea, Singapore and Taiwan, whereas the change in the Philippines shows any clear tendency. In the case of Malaysia, there is a fall of wage inequality during years 1970 and 1980.
} 
change in relative wage before and after trade liberalization in Costa Rica, they show the evidence that skill premium have increased when the economy is opened. The possible explanation of that increase is the existence of a change in the structural demand of labor. This later change is occurred because acceleration of capital importation after trade liberalization, affect positively the relative demand of skilled workers, and therefore relative wage. The structural change of labor market after trade liberalization have been also examined in Chili by Robbins (1994 a). The result shows that the wage of skilled labor increases. For the same country and by employing a time series analysis Beyer, Rojas and Vergara (1999) find a long-term correlation between openness and wage inequality. Hanson and Harrison (1999) and Verhoogen (2008) show an increase of wages inequalities in Mexico after trade liberalization. Verhoogen by taking in account product differentiation and firm heterogeneity explain these wage inequalities by the fact that the majority of the productive firms present in exportation market pay high wage.

Some others authors explain the increase of wages due to change in rents distributed after trade liberalization. Arbache and Menezes-Filho (2000) find a positive relationship between industry wage premium and tariffs reduction in Brazil. They prove that rents of goods market are strongly affected by trade liberalization, and that parts of rent are distributed to the labor market in the forms of higher wage premium through an increasing productivity. Attanasio et al (2004) show that the drastic tariffs reduction of Colombian economy at 1980s and 1990s, lead to an increase in the wage premium of skilled labor. This increase can be explained by the fact that the fall in tariffs was concentrated in the unskilled workers intensives sectors, causing a reduction of wage premium ${ }^{4}$ of unskilled workers relatively to skilled workers, (Goldberg and Pavcnik, 2005). Pavcnik, Goldberg and Schady (2004) observe the same evolution of wage premium of skilled workers in Brazil after trade liberalization. Attanasio et al (2004) find that trade reforms have affected wage distribution but with less amplitude. They argue that increases of wage premium are the causes of other factors than trade. Chen and Hsu (2001) study the effects of exportation on Taiwanese labor market. They distinguish destination of goods exportation: the exports of goods to less developed countries and exports of goods to OECD economies. The former have a benefit effect on blue-collar workers and reduce wage inequality while the former have to raise relative wages of whitecollar workers. As the developed world has a comparative advantage in conducting innovation, trade with this region leads Taiwan to produce high quality products whish induce firms in this country to upgrade their technology and employ labor that is more skilled. By employing a firm level data, Tan and Batra (1997) show that the important factor that affect wages inequalities in Taiwan is the investment in research and training, foreign exports have a positive effect on wages, but is relatively less important. Aw and Batra (1999) find that all workers in exporting firms in Taiwan earn a positive wage premium, more than 30 per cent for skilled workers and up to 14 per cent for the unskilled. Li and Xu (2003) however, study the direct and indirect impact of export intensity of firms in China on the relative share of the firm's wage payment to skilled workers. They find that the direct impact of exports on wage inequality is negative. However, they suggest that the exports yield a positive indirect effect on the wage gap via skilled-biased technologies. There are relatively few studies on African and South Asian countries. Mishra and Kumar (2008) show that trade liberalization contributes to the fall of wage inequality in India, while Bigsten and Durvall (2006) obtain the same result for Kenya. Ahmed and Sattar (2004) use a descriptive analysis between 1991s and 2002s, and argue that real wages in the manufacturing sectors in Bangladesh are in accordance with HOS model, the wage of unskilled labor rise more than skilled labor.

Evidence on labor demand: The majority of studies that assess the impact of trade liberalization on labor market use data on manufacturing industry. In the following, we are mainly interested by the labor demand side. Rama (1994) develops a model of monopolistic competition and uses a panel of 39 sectors to study the links between protection and employment in manufacturing sectors for Uruguay since 1979s and 1986s. He finds a positive and significant links, but no significant effect on the wages. Some other authors try to analyze the protection structure before trade liberalization in several countries, and in same time the intensity of qualification of sectors affected by trade reforms. The main observations of these analyses show that, contrary to predictions, unskilled labor intensives sectors are more protected before liberalization. This protection was observed in Colombian, Mexico and many others. These studies obtain the result that these sectors ${ }^{5}$ are more affected. Thus, by using Stolper-Samuelson theorem,

\footnotetext{
${ }^{4}$ Goldberg and Pavcnik (2005) define the wage premium as "the proportion of the individual wages that cannot be explained by the characteristics of worker, the firm, or work, but can be explained by the affiliation of the worker to industry".

${ }^{5}$ Sectors intensives in unskilled labor.
} 
demand of unskilled labor will be negatively affected. Feenstra and Hanson (1997) prove that American "maquilodoras" in north Mexico have generated a significant increase in the relative demand of skilled workers in the regions that are near U.S borders. They employ the between (inter-industrial variation) and within (intra-industrial variation) decomposition to test the increase of skilled labor. The calculation consists to measure the variation of the share of skilled labor in total employment or in wage bill. They note that the major part of demand structure is explained by the intra-industrial variation, i.e.: this variation is associated with the introduction of technology, which requires skilled labor. Menezes-Filho and Rodrigues (2001) also use the same analysis of decomposition and observe the same results for the case of Brazilian manufacturing after trade liberalization.

Revenga (1997) use an aggregate data for Mexico and find a negative link between tariffs and employment: if tariffs decrease, employment increases in industries. She does not find any significant statistical links between employment level and tariff when she used data at the plants level. However, she has found a significant negative impact between quota reduction and employment level of firm. Wood $(1994,1999)$; find an increase in the demand of unskilled workers in South Korea, Taiwan and Singapore after trade liberalization. This result is coherent with the prediction of traditional model; that the integration of the developing countries in world economy is accompanied by an improvement of unskilled labor situation. Currie and Harrison (1997) examine the evidence for the Moroccan manufacturing firms between 1984s and 1990s, and find a weak effect of trade on the level of employment. They conclude that the sectoral distribution of employment is relatively insensitive to trade reforms. In these sectors, a fall of $21 \%$ of tariff was associated with a fall of $6 \%$ of employment. They show that employment is sensitive to the changes of the production, but that the trade reforms did not carry out to meaning changes of the production. They justify such a behavior by arguing that this fact instead to adjust the levels of employment, much firms chose to reduce the marginal profit and to increase the productivity. Globally, empirical evidence finds a significant relationship between trade liberalization, wage inequality and employment. This finding is not consistent in majority of cases with the predictions of the HOSS standard trade theory. This implies that the impact of trade on employment is not done in a uniform way. However, the whole effect cannot be quantified due to difference in the magnitude of the positive or negative impacts. However, available empirical work let us think that openness was accompanied by a deterioration of wages and working conditions, in the majority of the developing countries. In recent years, the theory tried to explain this unexpected impact of trade liberalization on the labor market by allowing for many other assumptions not considered by the HOSS model. In the follows section we discuss in more detail that assumptions.

\section{What we can learn from theoretical explanations?}

Traditional explanation: The traditional HOSS model constitutes since long time an important framework to investigate the impact of trade liberalization on labor market. Following this theory, the country will specialize in the production of goods relatively intensive in abundant factor. Suppose that we have a simple model with two countries (developed country and developing country), two factors (unskilled labor and skilled labor) and two goods (one intensive in skilled labor and the second intensive in unskilled labor). With the same technology of production, the openness of trade between the two countries can lead to an expansion of goods exportation and importation. Developing country, which is specialized in the production of good intensive in unskilled labor, following its comparative advantage, will export this good. In another side, a developed country specializes in the production of good intensive in skilled labor and will export this good. Stolper and Samuelson established the relationship between the prices of goods and the price of factors. The important result of their theorem is that trade liberalization reduces the wage inequality in the developing country and vice-versa in the developed country through the change in the relative prices of goods. Consequently, in developing country, the relative price of good intensive in unskilled labor rise and, thus, increasing the relative wage of unskilled labor. In the developed countries, the relative wage of skilled labor increase. Therefore, trade liberalization increase wage inequality in developed countries and reduce it in developing countries. Like any analysis, the HOSS model is conceived on assumptions, which are specific and quite restrictive, that are often not able to capture reality. Some of its predictions are weakened (or even reversed) when one or more of these assumptions are relaxed (Winter 2000) ${ }^{6}$.

\footnotetext{
${ }^{6}$ The assumptions are as follows: the markets are in perfect competition, the factors are perfectly mobile between the sectors in the economy, the countries do not specialize in the production after trade liberalization,
} 
New explanations: However, one can envisage that is possible to extend the HOSS framework in order to account for multiple skill-related categories of workers (Wood, 1997), country groups (Davis, 1996), and traded goods (Feenstra and Hanson, 1996). In this case, the theoretical prediction of the HOSS model become undetermined and depends on the relative weights and directions of trade flows. Otherwise, if the assumption of production technology similarity among countries is relaxed, then trade liberalization may induce technology diffusion from developed countries to developing countries. These new technologies imported by DC are more skill intensive in relation to those in use domestically before trade liberalization. The expected result can be an increase in the relative demand for skilled labor and an increase in the gap of wages between skills.

Explanations based on HOSS model: The empirical evidences developed above can be considered as a first test for the realization of the HOSS model predictions. The results finding by this works triggered a large reconciliation tentative of the theory with the evidences by considering several extensions of original HOSS model. A simple extension of the model, which should reconcile the theory with the evidence, can be doing by introducing non-traded goods or additional factor of production in the model, Wood (1997). Suppose that there are two factors of production skilled labor, unskilled labor and land (natural resources). As assuming that some DC are relatively abundant in land, and that this land is a complement with skilled labor, then a great trade liberalization will favored the labor intensives goods in these countries. If the production of these goods requires a high ratio of skilled workers to unskilled workers, trade liberalization will be benefit for skilled workers. This argument is based on a non-realistic assumption that the lands require a high ratio of skilled labor. However, the inclusion of non-traded goods may reverse the outcome of model when there is a particular pattern of substitution between consumption of traded and non-traded goods (Leamer, 1995). For instance, in the developing economy with an abundant supply of unskilled labor, non-traded goods intensives in labor may be close substitutes to goods more intensive in skilled labor. Thus, greater openness reduces the price of the skill-intensive traded good, causing a rise of its demand and the fall of non-traded good demand. Consequently, demand for unskilled labor in the non-traded sector falls, which may not be offset by the rise in demand for this category in the traded sector (Wood, 1997). As a result, relative wage of unskilled workers drops in the developing world and widening the relative wage gap. Davis (1996) employ a "cone diversification" analysis to study the distributive consequences of trade liberalization. Accordingly, to him the problem is the relative position of a given country amongst the other countries within its own cone. The developing countries in this analysis are considered an unskilled abundant in global terms, but maybe are skilled abundant in local terms, in relation to other DCs. If we consider this later definition of abundance, the trade openness has the opposite impact on distribution of revenue of what we expect in a traditional HOSS framework (Davis, 1996). One can applied this argument to developing countries with middleincome. These countries are supposed unskilled-labor-abundant relatively two countries with highincome and skilled-labor-abundant relatively two countries with low-income. As a consequence, if middle-income countries liberalize their economies to trade, they have to face the competition of laborintensive manufacturing from low-wage, labor abundant low-income countries, and this can change their comparative advantages in labor-intensive exports, possibly resulting in a decrease in demand and wages for unskilled workers and in a wider wage gap.

Davis (1996) suppose in his model that there is threes goods differentiated in their capital intensity $(\mathrm{X}>\mathrm{Y}>\mathrm{Z})$. In equilibrium the North countries produce, $\mathrm{X}, \mathrm{Y}$, and the South countries produce $\mathrm{Y}$ and $\mathrm{Z}$. Thus, the North and the South forms tow different cones of diversification. The reduction of the tariffs will differently affect South countries according to the importance of production of each good $X$ and $Y$. The countries less developed, which export $Z$ and import $Y$, will see their inequality to fall: the wage decrease as the international price of $Z$ drops. The South countries more developed, which export $Y$ and import $Z$, will see an augmentation of their inequality: the world price of $Y$ drops, but since it is more capital intensive than Z, this leads to a high rent and weak wages. Outside the HO model, trade liberalization can potentially increase wage inequality in South (like in the North). The real impact of trade liberalization in the south is also ambiguous. Another explanation of the change observed on the labor market of DC is the recent increase in outsourcing or trade in intermediate goods and services. Feenstra and Hanson (1996, 1997) propose a North-South model where there is a continuum of goods used to produce a final manufacturing good with varying proportions of skilled and unskilled labor. In this model the continuum

the goods are homogeneous in same industry, technology are with constant output of scale, there are no non tradable goods, and the countries have access to the same exogenous technology. 
intermediate goods are indexed by $\mathrm{z} \in[0,1]$, so that a high $\mathrm{z}$ reflects a high intensity of qualification in the production. They assume that the capital is complementary with skilled labor; North has more of capital and skilled labor than the South. Is also assumed that the South has a comparative advantage in unskilled labor-intensive stages of production, and the North specializes in skilled labor-intensive stages. It can be demonstrated in equilibrium that there is $\mathrm{z}^{*}$ that the South produces the intermediate good in $\left[0, \mathrm{z}^{*}\right]$ and the North produces intermediate good in $\left[\mathrm{z}^{*}, 1\right]$. Openness of economy to world trade shifts the production of intermediate products (through trade and foreign direct investment) from North to South. Feenstra and Hanson (1996) argue that a production that is more unskilled intensive in the North become a skilled labor intensive in the South. In their model the increase in $\mathrm{z}^{*}$ generates an augmentation in the intensity of the average qualification in two countries, which rises the relative wage of skilled workers in two countries. However, insofar as technical progress is related to the international trade and supports the recourse to the skilled labor, one can admit the assumption of an indirect links of the trade to the wages inequalities. Zhu and Trefler (2005) do an extension of Feenstra and Hanson model to a case without foreign direct investment but with a Ricardian source of comparative advantage added to that based on factor endowment. In their model, the technological catch-up by the countries less developed causes a displacement in production of the unskilled-labor intensive Northern goods to Southern countries where they become the most skill-intensive goods produced. They retorted the result of Feenstra and Hanson and check this mechanism empirically. The results of this model are similar to the one proposed by Feenstra and Hanson, that there is a rise in the demand of skilled labor in both developed and developing countries.

Technological change induced by trade: The alternative explanation recently advanced in order to explain how openness to trade may affect labor market is the technological change induced by trade. A recent number of studies have pointed to skilled-biased ${ }^{7}$ technological change (SBTC), embodied in imported capital goods, as one of the most important factors causing wage inequality and skill upgrading to rise (Behrman et al., 2000; Esquivel and Rodriguez-Lopez, 2003; Pavcnik, 2003; Attanasio et al., 2004 ). In the case of developed countries, an intense debate has noticed between those, which consider that the trade liberalization is the first explanation of increasing relative wage, and those, which consider the technological change as the main cause of these increases. Currently, the most credible explanation of the deterioration of the situation on labor market during the last years, as valid for DC, suggests that interaction between trade liberalization and technological change is probably a determining cause of the increasing wage inequality. Leamer (1998) showed in his analysis that sector biased technological change is determining for wage distribution. At unchanged production prices and in general, equilibrium, biased technological change occurred in intensive unskilled labor sector benefits unskilled labor, whereas the biased technological change occurred in skilled intensive sector will profits skilled labor. However, if we distinguish between formal and informal sector, and that the former is relatively intensive in skilled labor, the argument could be made that the predictions of Stolper-Samuelson are not realized because of formal-biased technological change. Technology is biased toward the formal sector because of the wider availability of investment and skilled labor in the formal economy than in the informal economy. This bias increases the demand for formal workers, thus, widening the wage gap between formal and informal workers. The fact that trade opening promotes the spread of technology could, thus, explain an increase in the formal wage premium. Wood $(1994,1995$, and 1997) notes that the distinction between trade liberalization and technology can be scrambled because trade liberalization is a factor of the technology change occurred in some economies. In countries abundant in unskilled labor trade liberalization can be, often, skill enhancing. The demands of skilled labor increase and wages inequalities are reinforced. The trade increases the technology available. Domestic firms can accede to technology by importation Robbins (1995). Robbins (1996b, 1995) suggest that trade accelerate the processes of technology diffusion among countries and can generate immediately or at long term a biases against unskilled workers.

The mechanism in place can be resumed: a developing country, which decides to open its economy to world trade, will experience some technical change that would change the technology of production. This new technology is supposed to be biased against the unskilled workers. The final effect of such a change will be a relative increase of skilled labor demand, and subsequent a widening in the wage inequality.

\footnotetext{
7 "The biases of qualification" is difficult to measure, because the majority of the measurements employed in the literature are based on endogenous variables (such as, the share of the skilled workers in the wage bill of the firms) rather than an exogenous shock of technology.
} 
Indeed, the question that will be asked at this stage of analysis is to know if the increase of this relative demand is temporary or permanent. In other word, once that developing country have filled the technological gap and the technology becomes homogenous among countries, will the situation move back to the HOSS predictions? An attempt to address this question has been made by Pissarides (1997). The author argues that an increase in skilled labor demand is coupled with the transition from an inward oriented strategy to an outward oriented strategy. Pissarides do a links between the raised demands of skilled labor and the rise in the R\&D sector, which, naturally, stimulates a demand for this category of labor. As explained by Pissarides, once the period of transition is overcome, the wages dispersions tend to narrow until the original level is established. This alternative model differs from the Robbins approach because it identifies two periods: a period of transition, in which biased technological change generates similar results to those identified by Robbins, and a long-term period in which the wage dispersion should come back to the original levels. However, the analyses of Robbins not allow explaining why the technological change induced by trade is biased toward skilled labor. Recently, some study reconsiders this problem and show that the technological change is itself an endogenous response to trade liberalization ${ }^{8}$. In this case, one can say that the latter is indirectly responsible of the wage inequality increased. Wood (1995) advances the idea of "defensive innovation" to describe the response of firms to trade liberalization. Accordingly, to this assumption, the increase of trade liberalization leads firms to add new technologies not available before trade liberalization.

Thoening and Verdier (2003) formalize this idea and demonstrate that inequality rise in the North and in the South. This theory can be bracket to some developing countries, such as Latine American, which lived a significant period of trade liberalization in 1980s and 1990s. In this period, other countries, less developed, are entered on the world market (like China and India). The increases of competition (following this enter) in unskilled abundant sector can induce a fast technological change in this sector. Acemoglu (2003), presents a different mechanism through which the trade liberalization can induce (or accelerates) technological change. He develops a model of endogenous technology change, and argues that in the case of DC this technology change can be occurred following an increasing of importation of machines, equipments and capital goods, which are complementary to skilled labor. The trade liberalization reduces the prices of capital goods incorporating technology and, consequently, induces an increase of skilled labor demand in DC. Aghion, Burgess, Redding and Zilibotti (2003) advance another mechanism through which trade liberalization can affect technological change and thus indirectly wage inequality. In their model, the response of firms to trade liberalization depends of their position vis-à-vis to technical border. The firms, which are sufficiently close to the border, can survive. The firms, which are far, cannot be able to prevent the external entries. Consequently, the average impact of trade will depend on the fraction of the firms and the sectors, which are sufficiently close to the border. In general, the interaction between trade liberalization and technological change generate predictions, which are differed from the HOSS model result. Wage inequality can increase in the developed countries and developing countries. The production method within sectors can use labor that is more skilled. In this case, trade liberalization has a distributive affect without a significant price variation between skilled intensive goods and unskilled intensive goods.

\section{Are the country characteristics matter}

In general, the findings from trade and labor market empirical studies in the case of DC remains ambiguous and no conscientious have been reached until now. As noted in previous section, trade liberalization does not have the same impact on all developing countries especially in Latin American and East Asian countries. In the flowing section, we investigate some country-specific characteristics to know the causes of these divergent results between Latin American and East Asian countries.

Difference in the period of liberalization: The first work that has mentioned the possible increase of the wages gap between skilled and unskilled labor in the case of DC countries is the work of Wood (1997). This author suggests that the experience of the East Asian countries during the 1960 and 1970 decades supports the traditional theory prediction, following that the gap of wages between skilled and unskilled labor, for countries characterized by a high opened economy, tends to become lower. Since 1980s, Latin American countries have experienced the same process of trade liberalization than East Asian countries. The effect of this trade liberalization on wages inequalities shows an opposite result. Empirical results

\footnotetext{
${ }^{8}$ See Epifani and Ganica (2002), Xu (2001), and Yeaple (2003) for a recent analysis on the question of the technological change induced by trade.
} 
from Latin American countries show that since the half of 1980s, the increase of trade worsened the wage gap. Wood (1997) suggests also that the difference between the experience of these two regions is mainly due to the world economy change occurred between 1960s/1970s (the period in which East Asian countries used a outward oriented strategy) and 1980s/1990s (the period in which Latin American countries liberalizes their economies.), rather than the difference in economic characteristics between the two regions. As an example of that change, we find that the openness of countries with low income to the world economy in the beginning of 1980s. The effect of this change is the huge augmentation of unskilled labor supply, which has negative effects on relative prices of goods intensive in unskilled labor on world market and possible worsened of the relative remuneration of this factor.

The human capital endowment: The second reason, that is generally advanced to explain the difference that exist between the two regions is the priority given by Asian countries to policies oriented toward education and training. This politic is started before the decision to open the economy to international trade. The presence of lower education and qualification levels in labor market is an obstacle behind industrial development even in unskilled labor industries intensive. Therefore, an important work must be done such as education program and competence development, which are sensitive to demand change of labor. In addition, the labor market of emergent countries have been characterized by an increase of the demand of secondary and higher education in order to satisfy the new demand of qualification. These increases of skilled labor have reversed the tendency toward a widening of wage gap between skilled and unskilled labor after trade liberalization. Birdsall et al. (1995) argued that the increase of the demand of the secondary and high education supply have not only contributes to accelerate the growth in these countries compared to other countries, but also have reduced the difference of wages between skilled and unskilled labor. Robbins (1996b) attributes this fall of wage differential to supply side of market and in particular to the increase of skilled labor supply. Indeed, the author concludes that the effect of openness, in absence of supply change, would increase the relative demand of skilled labor, and consequently its relative wages. Spilimbergo et al. (1999) explain this difference by the importance of factor endowment of each country relatively to the average world effective supply of each factor. They note that, to a constant endowment, trade liberalization is associated to a higher inequality of wages in a panel of developing countries. They also show that developing countries, which were relatively less, endowed in human capital experienced lower inequality increase after trade liberalization. In Latin American countries, the increase of premium qualification of workers with a tertiary education is explained by the fact that there is a significant increase of relative demand of these workers after trade liberalization. However, as Robbins (1996b) has argued, the majority of studies have "....not explicitly considered human capital or formal education as determined endogenously within the trade process. Instead, such studies have usually incorporated relative supply shift only as controls that would allow them shifts in the relative demand for skill".

In the role of Natural Resources: The economies endowment in natural resources can be considered as another possible factor that explains the difference in results between the two regions. The countries of Latin America region are well endowed in natural resources than East Asian region, often not equitably distributed in the population. This endowment leads Latin American economies to export goods that are more primary. Abundant endowment in natural resources may lead to wage inequality since processed industries of primary goods are more skill and capital-intensive than low-skill manufactures. Therefore, increase in the returns from this factor during trade liberalization could benefit few owners (Bourguignon and Morrisson 1990). For instance, in a country like Brazil where land is unequally distributed, openness might lead to an increase in inequality. Such a phenomenon is much less likely to occur in countries where land was equally distributed at the onset of liberalization (South Korea for example). In the literature, Spilimbergo et al. (1999) and Fischer (2001) have examined the assumption following that endowment in natural resources is viewed as a possible factor to explain the increase in wage inequality. Their results indicate that while natural resources increase significantly the inequality, the trade in land-abundant countries has no clear effect. In general, taking in account the difference in natural resources endowment between the two regions do not refute the fact that trade liberalization benefit the relatively abundant factor in developing countries.

\section{Conclusion}

In this paper, we have presented and discussed theoretical and empirical evidences in the relationship between trade liberalization and labor market in DC. Theoretical works advance many explanations for these unexpected results of the impact of trade liberalization on labor market. The original explanation of 
the HOSS model, and the others extensions of this model, multiple skill-related categories of workers explanation (Wood, 1997), country groups explanation (Davis, 1996), and traded goods explanation (Feenstra and Hanson, 1996). The last one is that trade induce a technological change in DC (Wood (1997), Pissarides (1997), Robbins (1996), Acemoglu (2003)). Three major reasons have been presented in this paper in order to explain why there is a mixed result in DC when they opened their economies to international trade. The first reason is the difference in period of liberalization. The second is the difference in capital Human endowment. In addition, the last reason is attributed to the important role played by the natural resources endowment. It must be noted that the majority of empirical studies have been concentrated on Latin America and East Asian countries. There are few studies, which relate to the tweak income countries of Africa and South East Asia. The rarely empirical studies on the case of the African countries show also mixed results. Rattso and Torvik (1998) showed in the case of Zimbabwe that drastic trade liberalization, applied to the beginning of 1990s, had consequence a contraction of the output and employment and was accompanied by a big rise of imports and an increase in trade deficit. On the contrary, the study of Milner and Wright (1998) on Mauritius shows results much more favorable of trade liberalization. The fall of the protection for the local firms, which was applied during the time 198587, lead to a rise of employment in industries of exports but any contraction of employment in industries of imports. Two principal interrogations can be proposed on this level. The first is: can the traditional model of Heckscher Ohlin regain its predictive power by explaining the wage inequality or the changes of wages and the employment of these countries. Second, do these countries live the same experiment of East Asia of the fall of the wage inequality with a great commercial liberalization, rather than that of the Latin America? Clearly, these two questions can be answered by investigating the bonds between commercial liberalization and the labor market for much of these countries.

\section{References}

Acemoglu, D. (2003). Patterns of Skill Premia. Review of Economic Studies, 70, 199-230.

Aghion, P., Robin, B., Stephen, R. \& Fabrizio, Z. (2003). The Unequal Effects of Liberalization: Theory and Evidence from India. Working paper, Harvard, LSE, and IIES.

Ahmed, S. \& Zaidi, S. (2004). Trade Liberalization, Growth and Poverty Reduction the Case of Bangladesh, World Bank, Washington DC.

Attanasio, O., Goldberg, P. \& Pavcnik, N. (2004). Trade Reforms and Wage Inequality in Colombia. Journal of Development Economics, 74, 331-366.

Arbache, J. S., Dickerson, A. \& Green, F. (2004). Trade liberalization and wage in developing countries. The Economic Journal, 114(493), F73.

Arbache, J. S. (2001). Unions and the Labor Market in Brazil, Chapter 4 in The Third Dimension of Labor Markets: Demand, Supply and Institutions in Brazil, edited by Fransisco G. Carneiro, Indermit S. Gill, Ricardo Paes de Barros; The World Bank, USA.

Arbache, J. S. \& Menezes-Filho, N. (2000). Rent sharing in Brazil: using trade liberalization as a natural experiment. Annals of the $\mathrm{V}$ Annual Meeting of the Latin American and Caribbean Economic Association, Rio de Janeiro,

Aw, B. Y. \& Batra, G. (1999). Wages, firm size and wage inequality: How much do exports matter? In Innovation, Industry Evolution and Employment, D.B. Audretsch and R.Thurik (eds.), Cambridge: Cambridge University Press.

Behrman, J. R., Birdsall, N. \& Szekely, M. (2000). Economic Reform and Wage Differentials in Latin America, IADB Working Paper.

Berman, E. \& Stephen, M. (2000). Skill biased technology transfer around the world. Oxford Review of Economic Policy, 16(3), 12-22.

Beyer, H., Rojas, P. \& Vergara, R. (1999). Trade liberalization and wage inequality. Journal of Development Economics, 59, 103-123.

Bigsten, A. \& Durevall, D. (2006). Openness and Wage Inequality in Kenya: 1964-2000. World Development, 34(3), 465-480.

Birdsall, N., Ross, D. \& Sabot, R. (1995). Inequality and growth Reconsidered: Lessons from East Asian. World Bank Economic Review, 9, 477-508.

Bourguignon, F. \& Morrisson, C. (1990). Income distribution, development and foreign trade. European Economic Review, 34, 1113-1132.

Chen, B. L. \& Hsu, M. (2001). Time-series wage differential in Taiwan: The role of international trade. Review of Development Economics, 5, 336-354.

Currie, J. \& Harrison, A. (1997). Sharing costs: the impact of trade reform on capital and labor in Marroco. Journal of Labor Economics, 15, s44-s71. 
Cragg, M, I. \& Epelbaum, M. (1996). Why has wage dispersion grown in Mexico? Is it the incidence of reforms or the growing demand for skills? Journal of Development Economics, 51(1), 99-116.

Davis, D. (1996). Trade Liberalization and Income Distribution. NBER Working Paper 5693, National Bureau of Economic Research, Cambridge, MA.

Epifani, P. \& Ganica, G. (2002). The Skill Bias of World trade. Department of Economics, MIT, Cambridge, MA.

Esquivel, G., Jose, A. \& Rodriguez, L. (2003). Technology, Trade and Wage Inequality in Mexico before and after NAFTA. Journal of Development Economics, 72, 543-565.

Feenstra, R. C. \& Gordon, H. H. (1996). Globalization, outsourcing and wage inequality. National Bureau of Economic Research Working Paper. ${ }^{\circ} 5424$.

Feenstra, R. C. \& Gordon, H. H. (1997). Foreign direct investments and relative wages: evidence from Mexico's maquiladoras. Journal of International Economics, 42, 371-394.

Feliciano, Z. M. (2001). Workers and trade liberalization: the impact of trade reforms in Mexico on wage and employment. Industrial and Labor Relation Review, 55(1), 95-115.

Fischer, R. D. (2001). The evolution of inequality after trade liberalization. Journal of Development Economics, 66, 555-579.

Galiani, S. \& Sanguinetti, P. (2003). The impact of trade liberalization on wage inequality: Evidence from Argentina. Journal of development Economics, 72(2), 497-513.

Goldberg, P. \& Pavcnik, N. (2005). Trade, wage, and the political economy of trade protection: Evidence from the Colombian trade reforms. Journal of International Economic, 66, 75-105.

Hanson, G. H. \& Ann, H. (1999). Trade liberalization and wage inequality in Mexico. Industrial and Labor Relations Review, 52, 271-288.

Katz, L. F. \& David H. A. (1999). Changes in the Wage Structure and Earnings Inequality. In O. Ashenfelter and D. Card (Eds.). Handbook of Labor Economics, 3 (Amsterdam: North-Holland, 1999)

Krugman, P. R. (2000). Technology, Trade and factor prices. Journal of international Economics, 50, 51-71.

Leamer, E. E. (1995). A trade economist's view of US wages and globalization, in Susan Collins (ed.), Imports, Exports and the American Worker, Washington, D.C.; Brookings Institution.

Leamer, E. E. (1998). Wage inequality from international competition and technological change: Theory and country experience. American Economic Review, 86, 309-314.

Lee, E. \& Vivarelli, M. (2006). The Social Impact of Globalization in the Developing Countries. International Labour Review, 145(3), 167-184.

Li, W. \& Bin, X. (2003). Trade, Foreign Investment and China's Wage Inequality", University of Florida (Working paper available online on http://bear.cba.ufl.edu/xu/).

Menezes-Filho, N. A. \& Rodrigues, M. J. R. (2001). Openness, technology and skills: evidence from the Brazilian manufacturing. In Proceedings of the Workshop on Trade Liberalization and the Labor Market in Brazil. Brasília: UnB/IPEA.

Milner, C. \& Wright, P. (1998). Modeling Labour Market Adjustment to Trade Liberalization in an Industrializing Economy. Economic Journal, 108(447), 509-28.

Mishra, P. \& Kumar, U. (2008). Trade Liberalization and Wage Inequality: Evidence from India. Review of Development Economics, 12, 291-311.

Pavcnik, N., Blom, A., Goldberg, P. K., \& Schady, N. (2004). Trade Policy and Industry Wage Structure: Evidence from Brazil. World Bank Economic Review, 18(3), 319-344.

Pavcnik, N. (2003). What explain skill upgrading in less developing countries. Journal of Development Economics, 71, 311-328.

Pissarides, C. A. (1997). Learning by trading and returns to human capital in developing countries. World Bank Economic Review, 11, 17-32.

Rama, M. (1994). The labor market and trade reform in manufacturing. In M. Connolly, and J. de Melo (eds.), The Effects of Protectionism on a Small Country: The Case of Uruguay. World Bank Regional and Sectoral Studies, Washington, DC.

Rattso, J. \& Torvik, R. (1998). Zimbabwean Trade Liberalization: Ex-post Evaluation, Cambridge Journal of Economics, 22(3), 325-46.

Revenga, A. (1997). Employment and wage effects of trade liberalization: the case of Mexican manufacturing. Journal of Labor Economics, 15, s20-s43.

Robbins, D. J. (1994a). Worsening Relative Wage Dispersion in Chile during Trade Liberalization, and its Causes: is Supply at Fault? Development Discussion Papers No. 484, Harvard Institute for International Development, Harvard University.

Robbins, D. J. (1995). Wage dispersion and trade in Colombia: an analysis of greater Bogota: 1876-1989. Harvard University: Harvard Institute goes International Development, 1995. 
Robbins, D. (1996b). 'HOS hits facts: facts win evidence on trade and wages in developing world', Harvard Institute for International Development, Harvard University.

Robbins D. J. (1996). Evidence on trade and wage in the developing world OCDE development centre technical paper N0 119 December 1996.

Robbins, D. J. \& Gindling, T. H. (1999). Trade liberalization and the relative wages for more-skilled workers in Costa Rica. Review of Development Economics, 3, 140-154.

Robertson, R. (2000). Trade liberalization and wage inequality: Lessons from the Mexican experience. The World Economy, 23(6), 827-849.

Slaughter, M. J. (1998). International trade and labor market outcomes: results, questions and policy options. The Economic Journal, 108(450), 1452-62.

Spilimbergo, A., Juan, L. L. \& Miguel, S. (1999). Income distribution factor endowment and trade openness. Journal of Development Economics, 59. 77-101.

Tan, H. \& Batra, G. (1997). Technology and firm size wage differentials in Colombia, Mexico and Taiwan (China). World Bank Economic Review, 11(1), 59-83.

Te-Velde, D. W. (2003). Foreign Direct Investment and Income Inequality in Latin America. Experiences and policy implications. London: Overseas Development Institute.

Thoening, M. \& Verdier, T. (2003). A theory of defensive skill-biased innovation and globalization." The American Economic Review, 93(3), 709-728.

Verhoogen, E. A. (2008). Trade, quality upgrading, and wage inequality in the Mexican manufacturing sector. Quarterly Journal of Economics, 123(2), 489-530 05.

Winter, L. A. (2000). Trade, Trade Policy, and Poverty: What Are the Links? CEPR Working Paper 2382, Centre for Economic Policy Research, London.

Williamson, J. (1997). Globalization and inequality, Past and Present. World Bank Research Observer, 12, 117-135.

Wood, A. (1994.). North-South trade, employment and inequality. Changing fortunes in skill-driven world. Oxford: Clarendon Press.

Wood, A. (1995). How trade hurts unskilled workers. Journal of Economic Perspectives, 9, 57-80.

Wood, A. (1997). Openness and wage inequality in developing countries: the Latin American challenge to East Asian conventional wisdom. The World Bank Economic Review, 11(1), 33-57.

Wood, A. (1999). Openness and wage inequality in developing countries: the Latin American challenge to East Asian conventional wisdom. In: Baldwin, R.E., Cohen, D., Sapir, A., Venables, A. (eds.) Market integration, regionalism and global the economy. Cambridge: Cambridge University Press, 1999.

$\mathrm{Xu}, \mathrm{B}$. (2001). Factor bias, sector bias, and the effects of technical progress on relative wages. Journal of International Economics, 54(1), 5-25.

Yeaples, S. (2003). Firm Heterogeneity, International trade and Wages. Department of Economics, University of Pennsylvania, Philadelphia.

Zhu, S. C. \& Trefler, D. (2005). Trade inequality in developing countries: A general equilibrium analysis. Journal of international Economics, 65, 21-48.

\section{APPENDIX}

Table 1: Studies using regression of wages equations

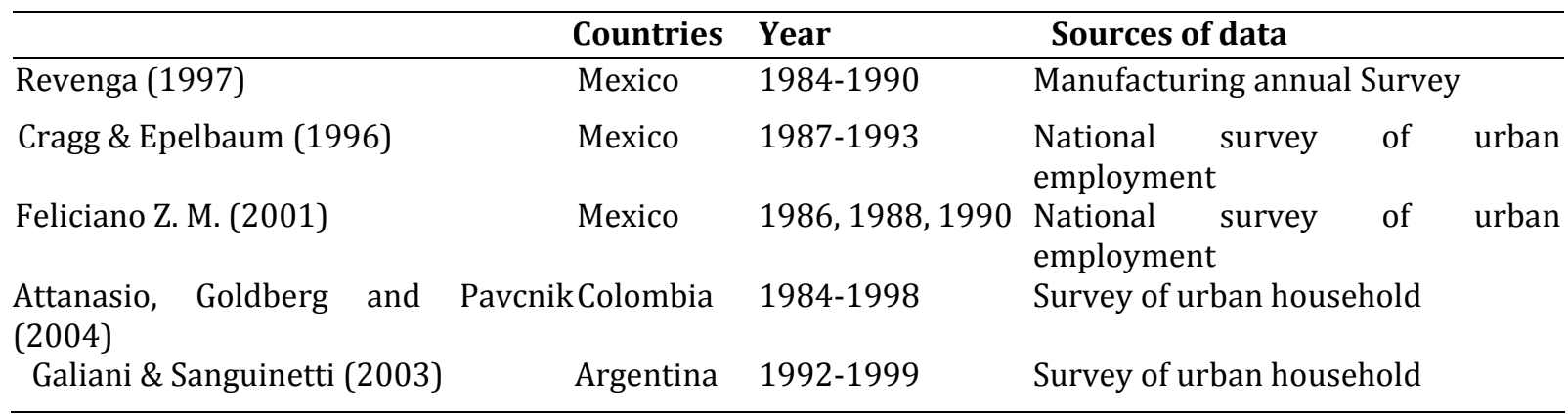


Table 2: Empirical studies using different approaches

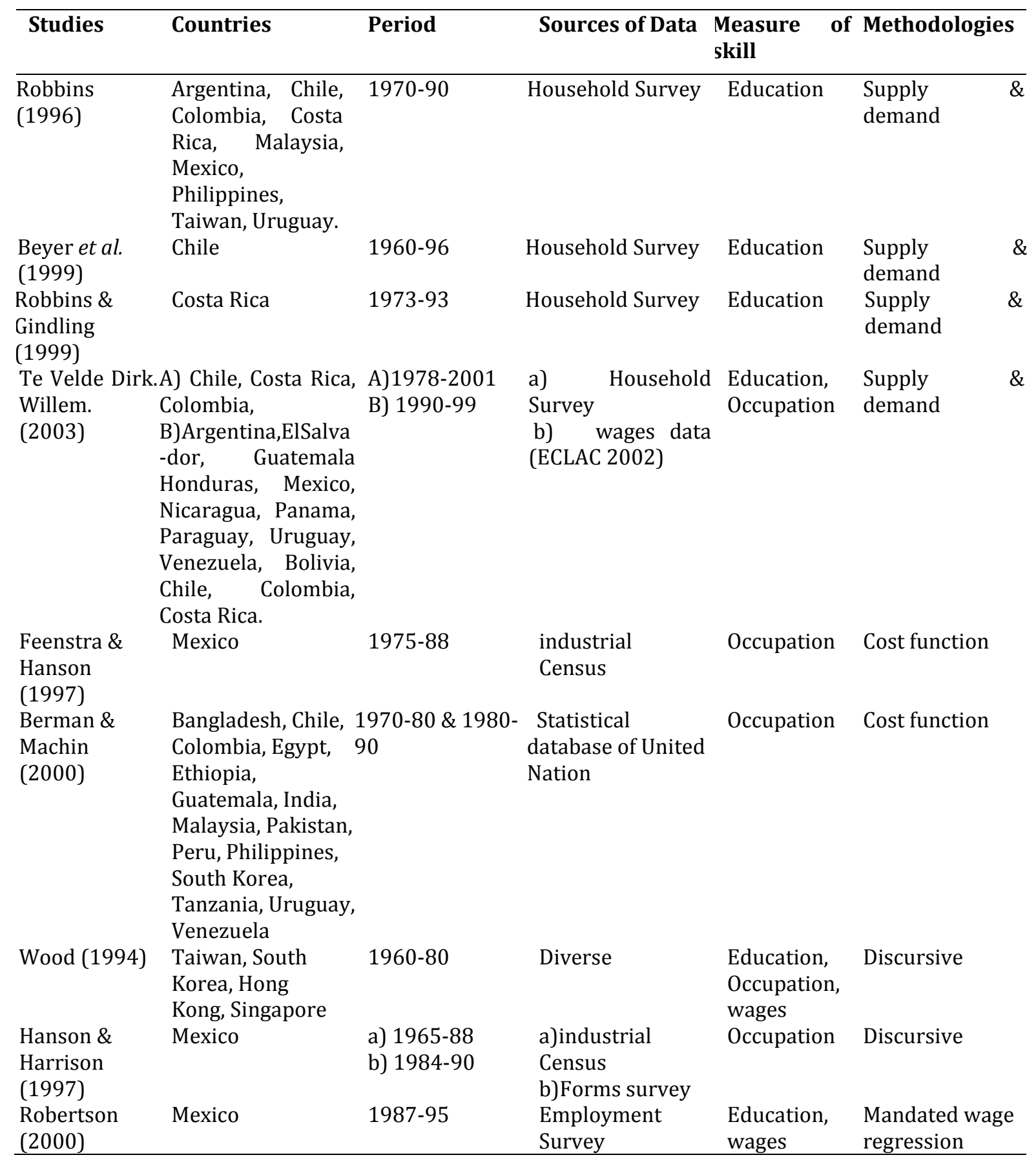

